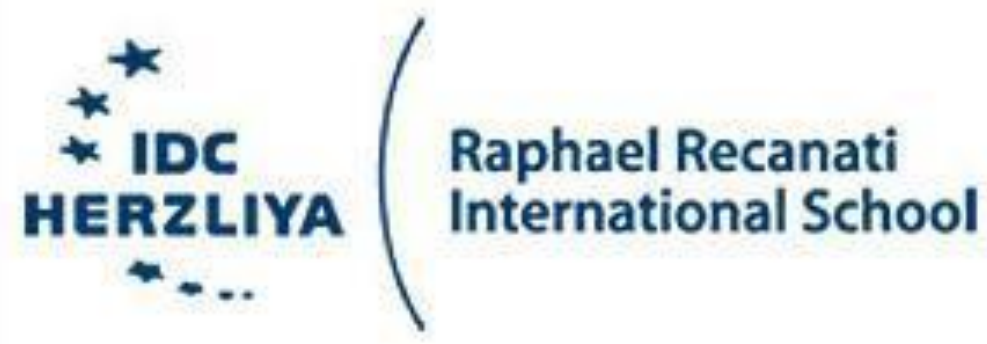

Seminar Paper :

Advanced Topics in Social Network Analysis

Lecturer: Dr. Tsahi Hayat

\title{
The Consumer Influence of Marketing in the Digital Age: A Meta- Analysis
}

Submitted by:

Miriam Young

Abigail Bergerbest

October 1, 2017 


\section{Table of Contents}

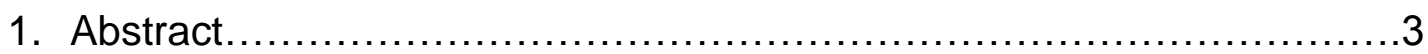

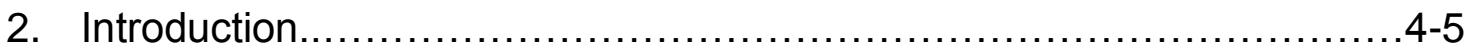

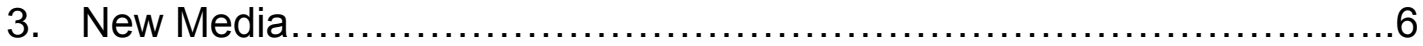

3.1. Six Characteristics of New Media...................................6-8

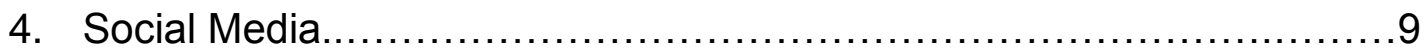

4.1. The Background of Social Media .................................... 9

4.2. Social Media: Definitions and Key Concepts.........................9-10

4.3. Data on World Use of Social Networks............................10-11

4.4. Looking at Top Social Networking Sites.............................11-12

4.4.1. Facebook ...................................................... 12

4.4.2. Twitter........................................................

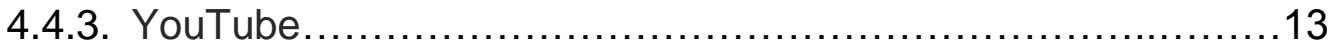

5. The Level of Involvement of the Consumer in the Purchase Process.......14

6. The Influence of Social Media on the Consumer.........................15-17

6.1. Comparing Worldwide Digital Influence..........................17-18

6.2. Facebook Fan Page and Twitter Influence ..........................18-20

7. What Do We Purchase Online? ........................................21-23

8. The Influence of Social Networks: Word of Mouth Communication........24-26

9. The Engagement Between Consumers and Brands in the Digital Age....27-28

9.1. The Consequences of Emotional Involvement in Commercial

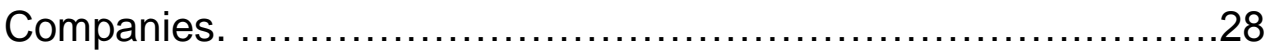

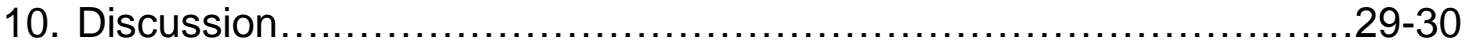

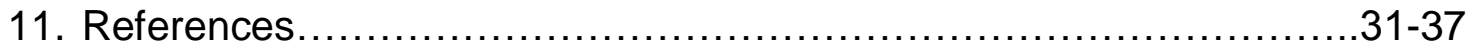

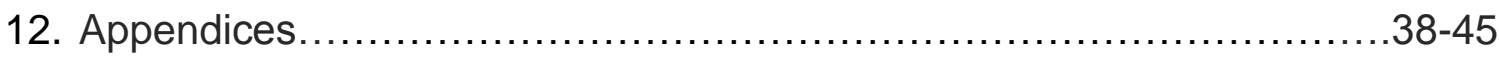




\section{Abstract}

This study addresses the issue of the shift from traditional to new media marketing and its effects on the relationship between brands and consumers. Through a systematic analysis of 53 articles and research studies on an array of topics within digital marketing, this paper summarizes the main findings and compiles the major research trends. Through an aggregation of the surveys and studies existing in the current field, the following analysis was constructed, in order to form a dynamic representation of the developments within the process of consumption. The examination of consumer behavior refers to different areas, which were deeply investigated here, including: consumer levels of involvement, the various methods of information transfer, the multiple social networking platforms, and the ways these are utilized towards purchasing decisions. As this topic has become so intertwined in the marketing world today, this meta-analysis serves as a compilation of the major works of the past twenty years, leading up to this shift in ever-changing levels interactivity. With the introduction of the digital age, the Internet, which didn't initially possess such transparent ties to the field of consumerism, has managed to reinvent and redefine the entirety of its inner workings. 


\section{Introduction}

With the birth of New Media, a new era of the Internet began.

The retail field was thrust into a rapid period of changes in lifestyles and expectations, affecting the global process of consumerism. Social networks have taken over the general interest of the population and now have an immense input on all areas of decisions and intentions, in this case more specifically regarding purchase decisions. A prominent shift has been the sophistication of consumers regarding a variety of purchase options and price comparisons, empowering the consumer to make decisions on a new basis. This studies the change in consumer behavior that arose with the digital age and even more so with social media.

As the Internet made an appearance into our lives, and with the current dominance social media has usurped in our daily routines, the ways in which consumers communicate with one another has been revolutionized. This phenomenon exposes the ways in which consumers exchange information about different products, sweeping this change across to even the very methods of consumption. Various new communication platforms supply the consumers with all new options, involving new product informational updates and consumer sharing. These changes force the business world to be closely following the shift of power and communication, remaining on high alert in order to preserve their market influence and abilities. In order to succeed in marketing today, retailers need to shift their focus on the consumer towards modern retail strategies online, which requires information about the consumer behavior, intentions, expectations, and profiles.

The main focus of this paper is to examine the function that social media has on purchase decisions, exposing how what people post online actually effects what others consume in real life. This is the start of unprofessional opinions holding a greater influence than that of corporation positions. Beginning with defining new media and social media and providing extensive background on both, we identify key concepts that explain the changes in behavior that are ultimately influencing purchasing decisions. We evaluate how new media has 
redefined each of the different stages of the purchasing process, with one of the most drastic evolutions existing within the search for information.

\section{New Media}

The way consumers communicate with each other has changed dramatically throughout the past decade. This change is relevant to the way in which consumers exchange information about different products and their methods for purchasing them. Through the use of new media and all of the various platforms available today, consumers are enabled to efficiently spread ideas and information. The consumer role has developed into a highly opportune and creative position, where online they have the new ability to be sellers, producers, directors, creators, etc. Using new media and websites such as YouTube, Wikipedia, Ebay, and Instagram, the regular consumer can take on new roles. While in the past, in order for one to have the opportunity for this sort of position, one needed a different level of experience in the field, today, thanks to modern technology, accessibility, and mobility, any individual can take on these roles and exchange information in real time.

Hennig-Thurau et al. (2010) define the concept of New Media in their article titled "The Impact of New Media on Customer Relationships": "New media are websites and other digital communication and information channels in which active consumers engage in behaviors that can be consumed by others both in real time and long afterwards regardless of their spatial location" (Hennig-Thurau et al., 2010). Their research identifies six specific characteristics that are present in the realm of New Media.

\subsection{Six Characteristics of New Media}

The first characteristic identified is "digital". Because New Media exists digitally, it allows for the large-scale distribution of ideas throughout the world, at a lower cost, without having to go through the former process involving "'gate keepers' such as publishers" (Hennig-Thurau et al., 2010), or other professional positions that used to be needed in the spread of information. Anyone who can 
access the Internet, now has the power to share their ideas and creations in a way that was unfathomable even up until a few years ago. Everybody can be used as a source- reporting, creating, sharing, reviewing, exposing information freely, regardless of their professional background. According to Pew (2015B) a steady increase was seen in American adult Internet usage, growing from $52 \%$ in 2000 to $84 \%$ in 2015. (See Figure 1)

The second characteristic, "proactive", Hennig-Thurau et al., drew from the idea of Hoyer et al., in their 2010 study titled "Consumer Cocreation in New Product Development". New Media supplies consumers with the opportunity to be proactive. On a small scale, they can now express themselves and comment, but for those who are interested, much larger opportunities are available. People can now cooperate with other consumers online, to further their shared agendas, and even collaborate with professional corporations. Together, these all contribute to the overall database of the Internet.

Characteristic number three discussed is the concept of being "visible". Most consumer activities through New Media are open and exposed to anyone. Online actions such as entering forums, blogs, and social communities, are openly available for both consumers and commercial companies, to view and track. Furthermore, online services can be aggregated by location. This enables the optimization of location-sensitive information to reach the consumer, in order to best accommodate their needs. The consumer can also see where other users are located, what they're looking for, and what their opinion is, generating and encouraging stronger consumer involvement.

The fourth characteristic present in New Media is "real-time and memory". New Media allows the consumer to share his or her experience in real time (through a variety of social media, including Facebook, chats, and blogs). This content may exist online forever, so a potential consumer any time in the future can read about the shared positive and negative experiences.

The fifth characteristic discussed is the idea of New Media being "ubiquitous" (Amichai-Hamburger \& Hayat, 2017). New Media allows consumers both to reach others and be reached by others, including individuals and 
commercial companies. This process has been simplified and made so accessible in real time through users mobile devices (Hayat \& Samuel-Azran, 2017). The example of movie reviews was discussed in this paper and is a prime display of this in action. An individual can post a review of a new movie, on it's opening night, while the credits are still rolling. In the past, a movie was reviewed by a professional critic who published their thoughts through professional platforms, at a later time. This fast spread of new information by the consumers, for the consumers, represents the shift and the strength of power to the consumer, introduced by the digital age.

The sixth and final characteristic of New Media is "networks". A main area of interest for New Media users is social networking websites (e.g., Hayat et al, 2017; Hayat et al, 2016). These sites have grown drastically in just a few years, with billions of users from around the world, connecting with others who they may or may not know, sharing similar interests (Hennig-Thurau et al., 2010).

\section{Social Media}

\subsection{The Background of Social Media}

There are various ways to define "social media". According to Riegner (2007), social media is a virtual community that was created in order for people to connect to others using Internet based tools, such as email, chat, blogs, etc. The idea is for people to be able to contact others who share similar interests; this includes everything from hobbies to networking, to business connections. Boyd \& Ellison (2007) define social networking sites as online platforms that allow individuals to create a public or personal profile, on which they can establish connections with others.

\subsection{Social Media: Definitions and Key Concepts}

The concept of "social media" describes different platforms that allow creating social connections and sharing information. According to Kaplan and Haenlein (2010) as discussed in, "Users of the world, unite! The challenges and 
opportunities of Social Media", in order to define social media, there are two main concepts to recognize: Web 2.0 and User Generated Content (UGC).

Web 2.0 is the general name for the technological and ideological development of social platforms. This describes the new way the Internet is used by both software developers and individuals. The content and the applications were previously created in an official editorial and concentrated manner, while today there are a variety of personal websites, blogs, and collaborated projects such as Wikipedia.

"User Generated Content (UGC) can be seen as the sum of all ways in which people make use of social media" (Kaplan \& Haenlein, 2010). The UGC is a database reflecting the ways in which those who surf the Internet use social media. The concept of UGC refers to the different methods in which these users create public content. On the basis of the concepts described above, Kaplan and Haenlein (2010) define social media as "a group of Internet based applications that build on the ideological and technological foundations of Web 2.0, and that allow the creation and exchange of User Generated Content."

Kaplan and Haenlein (2010) introduce six types of social media that can be classified by social presence/media richness and self-presentation/selfdisclosure. (See Figure Two)

The first two discussed are "blogs" and "collaborative projects". The level of self-presentation and self-disclosure is higher in blogs than in collaborative projects. This is due to the content in blogs usually being more personal and linked to a specific individual, while collaborative projects such as Wikipedia remain anonymous.

The following two topics are "social networking sites" and "content communities", which are located higher in the sense of social presence and the fact that they are based on text. These also allow photo and video sharing, as well as other forms of communication. There is more self-presentation/selfdisclosure occurring on social networking sites than content communities because of the person information the user provides on their profile. 
"Virtual social worlds" and "virtual game worlds" are the final two discussed. These types of social media are located in the higher level of social presence and media richness. In terms of self-presentation/self-disclosure, virtual social worlds possess a higher level of exposure because the more they use these sites, the more they begin to depict their real-life world in their virtual social world (such as in Second Life), exposing their true identity. Virtual game worlds don't have this same sense of identifying ones self because aside from a few login details, there isn't much personal information to share (Kaplan \& Haenlein, 2010).

\subsection{Data on World Use of Social Networks}

Looking at various reports, there is a compilation of data that can be understood about world social network usage. In "State of The Media: The Social Media Report", a study done by Nielsen (2011), "The Demographics of Social Media Users", done by Pew Internet \& American Life Project (2013), and "It's a Social World: Top 10 Need-to-Knows About Social Networking and Where It's Headed", done by ComScore (2011), results showed that over $80 \%$ of the world population surf the Internet, and around 1.2 billion of these people use social networking sites. Pew compared the use of social networks from the years 20052011 and found that over this time there was a drastic increase in users. In 2005, only $8 \%$ of adult Internet users reported social network usage, which grew to $29 \%$ in 2008 , and $65 \%$ in 2011 . (See Figure 3)

In the survey conducted by Pew Research Center's Internet \& American Life Project, "The Demographics of Social Media Users - 2012", it was found that at the end of $2012,67 \%$ of all Internet users in the United States used social networking sites, with a stronger presence of female users than that of male. It also found that with age, the percentage of users in social networks decreased, with the most concentrated population between the ages of 18-29. The Nielsen (2011) data shows nearly 4 out of 5 active Internet users visit social networks and blogs and $40 \%$ of social media users access their network through their smartphone devices. 
The social network is a global cultural phenomenon. Although throughout the world there are significant differences in terms of regulations, availability, Internet access, cultural differences, social network usage is constantly expanding everywhere. In most first world countries, an average of $90 \%$ of Internet users are active on social media (ComScore, 2011A).

\subsection{Looking at Top Social Networking Sites}

"Most Facebook users are actively engaging with their networks on the site. As opposed to simply reading or viewing content, $65 \%$ of Facebook users frequently or sometimes share, post or comment on Facebook" (Pew, 2015A). Looking at the United States population, while Facebook has stayed in the lead as the most frequently used social networking platform, in recent years, Twitter, Instagram, Pinterest, and Linkedln have gained more popularity and growing at a quicker rate. (See Figure 4)

From the Pew (2015A) findings, the quick rate of multi-platform social media usage can be seen. In 2013, $42 \%$ of Internet users were present on more than one social networking site, and by the next year, there was a $10 \%$ increase. Instagram was a monumental turning point in social media, with $53 \%$ of all young adult Internet users between the ages of 18-29 using Instagram, and half of these logging in daily, towards the end of 2014. Linkedln also reached a new high at this time, with $50 \%$ of college educated Internet users participating. Pinterest, too, gained momentum then, with the highest differentiation of participation on these sites, due to gender. Of women using the Internet, $42 \%$ use Pinterest, compared to only $13 \%$ of men.

\subsubsection{Facebook}

When Facebook was founded in 2004, by Mark Zuckerberg and others, it began as a site for viewing other students and ranking their attractiveness, first on Harvard's college campus, before then expanding to other universities. However, it quickly expanded into the most popular social network worldwide 
(ComScore, 2011A). Facebook describes itself as a "social service" with the goal of helping people effectively communicate with friends, family, and co-workers. The difference between Facebook and other online based social services is that "Facebook is an application platform on which the interaction between individuals through applications create the content (collective)" (McClard \& Anderson, 2008). According to Facebook's financial reports for the first quarter of 2013, the number of world users was at 1.12 billion people, with 751 million users accessing the site from their smartphones, and overall 665 million active daily users.

\subsubsection{Twitter}

Twitter began in 2006, established by Dorsey and Williams, as a social network and a microblogging service. The concept of microblogging, which Twitter is based on, is a form of communication that operates through creating content on a short form that allows users to post updates called "tweets". Twitter allows users to receive information in real time, connecting users to stories, ideas, opinions, and news, containing links to resources, pictures, or video clips (Letierce, et al., 2010). Twitter is one of the most popular online activities among technology fans in the United States and it became a useful tool among analysts who are interested in studying about the conversations of users and products, services and messages of companies, and public institutions (Pew, 2012B). In a more recent and general Pew survey, it was found that among popular social networking sites today, Twitter is used the least, with only $23 \%$ of online adults active there in 2014 (Pew, 2015A). In order for retailers to most effectively use Twitter, they need users to "follow them". By doing so, users can be updated about popular products and special deals, making this a valuable communication channel for efficiently reaching users (Letierce, et al., 2010).

\subsubsection{YouTube}

YouTube was founded in 2005 by three PayPal employees, Steve Chen, Jawed Karim, and Chad Hurley, as a video-sharing site. YouTube also functions as a forum where people can connect with each other, inform one another about 
different content, and inspire others worldwide (Latta \& Thompson, 2011). According to YouTube Statistics listed on their site, they have over 1 billion users. Hundreds of millions of hours of videos are watched, creating billions of views on a daily basis. The number of hours people spend monthly watching YouTube videos goes up yearly by $50 \%$. Every minute there are 300 hours of video footage uploaded to YouTube and half of YouTube views are accessed through mobile devices (YouTube Statistics, 2015). Because users see forums as a source of information, marketers began studying the field of virtual communities and learned how to integrate and utilize these within their product site. (Bagozzi \& Dholakia, 2002).

\section{The Level of Involvement of the Consumer in the Purchase Process}

"Purchasing involvement has been one of the central issues in the consumer behavior literature because it can be an important mediator of consumer behavior, which can fundamentally influence the consumer's evaluation processes on certain objects" (Lakshmi, 2011). When making a purchase, there are various levels of risk involved for the consumer, indicating level of involvement. While purchasing a more expensive item that is more likely to be widely viewed by others (such as a car or a house), the consumer automatically feels at higher risk and exerts a greater effort in their product investigation. This investigation process differs between individual consumers depending on the sentimental value and their personal background, as well as their knowledge in the area of purchase. The final prominent factor in consumer product hunt decisions is the aspect of time and scarcity of the item (Beatty \& Smith, 1987).

"Several researchers have carried out studies in their effort to examine the factors influencing consumers' attitude and perception to make online purchases... Attitudes toward online shopping are defined as a consumer's positive or negative feelings related to accomplishing the purchasing behavior on 
the Internet" (Jusoh \& Ling, 2012). The Internet is an easily accessible database of enormous amounts of quality and personalized information, which helps in psychologically appeasing the consumer's worries of risk when making high level involvement purchases. Therefore purchasing online is beneficial for decisionmaking, as the risk level is already lessened there (Chai, Ling, \& Piew, 2010). Consumers use social media at a rate of growing frequency, when searching for information and looking for answers regarding various products. The move to these forms of new media, takes consumers a step away from traditional communication channels (Lempert, 2006).

\section{The Influence of Social Media on the Consumer}

Social media introduced new opportunities to the consumer and reinvented the idea of consumption. Due to the control of the flow of information in the past, the consumer was exposed to specific content that was pre-filtered and edited. Nowadays, when a consumer is searching for information about a company, they can search on Google and will be able to access the official company site, along with other relevant results provided by outside sources. Companies can no longer censor the information consumers can access about them, because anyone can provide different views online, at any time (Kaplan \& Haenlein, 2010).

Traditional means of communication are becoming outdated in terms of marketing. The Internet in general, and more specifically social media, is used as a subsequent replacement for traditional communication, even becoming a central communication mean for consumers. The most dramatic change is the ability of consumers to communicate with each other in real time and swap information (Li \& Bernoff, 2008).

In a study done by Beyond \& Lexis (2011), research showed that websites rich in information have a stronger impact on consumers that have high levels of involvement in the product, while on social media, there's a strong influence on consumers who have a low level of involvement in the product. Examples of low involvement levels would be products within the realms of fashion, beauty, and 
music. Still, not enough research has been done about the subject of "low level of involvement" in the digital age. Beyond and Lexis found that low level participants are not searching for information, however are instead sensitive to different stimulations that social networks can provide. This opens up an opportunity for different companies to build an emotional connection to a brand, leading to loyalty and raising the level of involvement in a product. Furthermore, findings showed there is a higher chance for the existence of purchase intentions when the consumers are searching for information on the brand website and product review sites. On the other hand, consumers who used social networks were found to act not from purchase intentions but from seeking entertainment, information, and social interaction. More findings showed that social network users are divided into two types: active (20\%) and passive (80\%). The likelihood that an active user would use social media to recommend a brand to a friend is three times higher compared to a passive user. (See Figure 5)

In the age of social media, the amount of information spreading by word of mouth between consumers has infinitely increased. This effects the process of decision making of the consumer, starting from researching a product prior to purchase, through the actual act of purchase, and finally the aftermath of the purchase (Mangold \& Faulds, 2009).

There are a number of characteristics involved in the information search process in the digital age. The first one is "interactive"- the use of the Internet is the process of interpersonal interaction (word of mouth communication), which eventually improves the availability of the information, lowering the cost involved in information search and distribution (Chai, Ling, \& Piew, 2010). Furthermore, the Internet provides a direct link between brands and the consumers, unlike the one way communication which exists in traditional communication platforms. The second characteristic is "information availability"- the Internet provides endless information, which has been made accessible practically any place or time (Peterson \& Merino, 2003).

In a 2011 study done by Pew Internet and American Life Project, it was found that around $60 \%$ of users who access the Internet through three or more 
digital devices, discover brands and stores through social media. Of these highly connected users, $48 \%$ of them went a step further and purchased items that stores were promoting through Facebook or Twitter (Pew, 2011). "The Consumer Barometer", a collaborative world effort of Google, European IAB, and TNS Research Institution, has the goal of quantifying the role of the Internet in the consumer decision-making process. The information compiled, takes into account every step the consumer makes from the initial market research, up until the actual purchasing point. This 2012 research found that the higher a desirable product was priced, the more extensively a consumer would research this item.

\subsection{Comparing Worldwide Digital Influence}

Research done by Fleishman-Hilard (2012), measured the digital influence on purchasing decisions, beginning in 2009, comparing between eight countries that represent more than half of the online population in the world. Studying data from Canada, China, India, France, Germany, Japan, United Kingdom, and United States, they looked into the central aspects of consumer Internet use, including patterns of media consumption, the level of adaptation to new forms of digital behavior, levels of involvement in social networks, and ultimately how they all effect the purchase decision. According to this research, consumers utilize the Internet in order to gain information and moral support, so they can make educated purchasing decisions. The two areas of interest most accessed online in terms of purchases and services are: children and health related topics. $93 \%$ of the population within the study reported the Internet to be useful in their search to juxtapose products when purchasing electronics. $88 \%$ reported a reduced price due to online services when making travel \& leisure purchases. $87 \%$ use the Internet to save money in the field of education. (See Figure 6)

Online search engines continue to be the most important tool that consumers rely on when making purchase decisions. The second most common information source is Internet websites of brands or products. Specific price comparison websites have been gaining popularity, especially in fields such as education, health, travel \& leisure, and electronic devices. It was also noted that 
consumers use social networking sites in their search for information- $24 \%$ use forums, $18 \%$ check the brand Facebook page, 14\% use the brand Twitter page, and $12 \%$ search reviews and comments that people have "tweeted" about a product. The country which uses Facebook brand pages for finding information most often was India which reported 35\%. (See Figure 7)

Furthermore, the research discovered that almost two thirds of consumers used cell phones to gain information about products, brands, or destinations, at least 3-4 times weekly. $80 \%$ of smart phone users have GPS location services and half of them reported using these to gain information, offers, discounts, and sales.

Haubl and Trifts (2000) studied the online purchase environment and claimed that it allows the consumer to invest less effort in decision-making because of the excessive amount of information and product comparison made so easily accessible. Because the Internet offers a display of data and information-comparison between various alternatives, consumers may reduce the cost of search and effort when looking to buy a product (Peterson \& Merino, 2003).

\subsection{Facebook Fan Page and Twitter Influence}

"Engaging consumers in interactive marketing communication is instrumental in business-customer relationships building and development. Social media enables consumers to initiate marketing messages and gain growing control in the communication process due to its enhanced interactivity features" (Zhang \& Yi, 2015). Fleishman-Hillard (2012) created a "Digitial Influence Index" showing why consumers around the world follow brands on social networking sites. The top reasons people gave for following brands on social media were respectively, to learn more about the brand, receive discounts or coupons, obtain exclusive information, give positive feedback, and share their opinions. (See Figure 8)

Facebook fan pages are a prime location for companies to connect with consumers in a non-threatening environment, where the consumer will already 
be spending time exposed to a wide compilation of information they have chosen to engage with, from personal and public resources. "Brand fan pages reflect part of the customers' relationship with the brand, broaden the brand-customer relationship, and provide a source of information and social benefits to the members" (De Vries, et al., 2012). While in the past, it would be considered too pushy for a company to be reaching out and trying to connect with their customers more often than when sharing big news or important information, Facebook brand pages have introduced the perfect balance for the push and pull of their message. Most brands have an online presence, and consumers can choose to 'like' their Facebook pages in order to stay connected. Facebook algorithms are designed so more of what the user is interested in interacting with appears on their feed, and posts they don't engage with will show up less. (De Vries, et al. 2012).

Even unintentionally, users share information by 'liking' or commenting on a Facebook brand post. Spreading in the same way as word of mouth communication, this can amplify the magnitude of the post. Because of this, it is highly beneficial for companies to share engaging posts, to receive a greater number of likes and shares, that will result in larger viewership. Here is an example of how all publicity is good publicity. On Facebook fan pages, De Vries, et al. (2012) tested various characteristics of posts in order to determine which lead to the most likes and comments. They found that both positive and negative comments on a post enhance general interest in the post, leading to higher overall exposure. In order to gain more likes, vivid and interactive posts are most effective. A vivid post would be one that stimulates the different senses (Steuer, 1992). Interactivity is defined as "the degree to which two or more communication parties can act on each other, on the communication medium, and on the messages and the degree to which such influences are synchronized" (Liu \& Shrum, 2002). To garner more comments, they found it best to best to take the interactive approach and ask a question (De Vries, 2012).

Twitter is the most real-time platform that a brand can communicate through. Chu \& Sung (2015) proposed in their study, that "peer communication, 
brand-related factors, and Twitter usage motivate brand followers to share eWOM [electronic word of mouth] messages on Twitter." They found that there are specific Twitter users who reach out to brands through this platform, including people following the brand who are: social influencers, Twitter users who commonly interact positively with brands on Twitter, and heavy Twitter users who follow many brands. Users in a similar demographic are those who are 'retweeting' the links that brands post. 'Retweeting' or 'favoriting' a brand post on Twitter is the equivalent on this platform to liking/commenting/sharing on Facebook (Chu \& Sung, 2015). 


\section{What Do We Purchase Online?}

"The Web experience embraces elements like searching, browsing, finding, selecting, comparing and evaluating information as well as interacting and transacting with the online firm. The virtual customer's total impression and actions are influenced by design, events, emotions, atmosphere and other elements experienced during interaction with a given Web site, elements meant to induce customer goodwill and affect the final outcome of the online interaction" (Constantinides, 2004). (See Figure 9)

Over a seventeen month period from February 2012 - June 2013, data was collected through online surveys, representing 5,657 interviews about shopping and social media. With participants from the United States, Canada, and the United Kingdom, Nanji (2013) was able to study the influence of Facebook, Twitter, and Pinterest (three top social networking sites) on the decision making and execution of online and offline purchases. Among other information, it was found that Pinterest qualified as the social network with the highest likelihood of resulting in a spontaneous purchase. Contrastingly, products seen through Twitter and Facebook were less likely to be purchased impulsively and were usually researched deeper before. It was found that half of the purchases made related to social media were done within the first week from the moment a product caught their interest (Nanji, 2013).

One of the most popular subjects investigated in the field of Facebook usage is the concept of marketing through social networking sites. This is a dynamic subject that is ever-changing at a rapid pace, with usage habits varying between differing communities and countries. Digitas Research (2012) found that a sense of security by the user is the key to the growth and development of these online social purchases, and $55 \%$ of social media users reported feeling uncomfortable submitting their credit card details over social networking websites. They also discovered that around $75 \%$ of social media users agreed that they tend to purchase through a Facebook brand store that was recommended by a friend, however Facebook purchases most occur only when 
there is something uniquely being offered on this platform, and at a reasonable price (Digitas, 2012). From data collected in the United States by a company called Technorati (eMarketer, 2013), Facebook was seen to be the social networking site with the highest level of influence among Internet consumers in the United States, even if the purchases weren't finalized through Facebook. At the start of 2013, United Parcel Service (UPS) conducted a survey among 3,000 customers. Results showed that over $50 \%$ of smartphone users are utilizing these devices to shop online. The Google Shopper Marketing Agency Consul (2013) showed that $84 \%$ of smartphone owners actually put their mobile devices to use even when shopping traditionally, offline, in order to make price comparisons and find further information such as reviews towards the products or stores. (See Figure 10)

In the 90's it was found that the key to long-term profit was customer loyalty (Reichheld, Markey \& Hopton, 2000). Today, with the click of a button, consumers can effortlessly reach websites providing them with alternatives and sometimes better priced, and quality products. Such a vast array of websites are available to help facilitate the purchasing process, that great concern has arisen among market managers and large commercial companies. The concern is that customer loyalty is becoming harder to achieve and maintain due to myriad of offers that the consumer is exposed to, with the click of a button (Shankar, Smith, \& Rangaswamy, 2003). Koufaris reiterated this in his 2002 study titled "Applying The Technology Acceptance Model and Flow Theory to Online Consumer Behavior", adding that in cases of online purchasing, loyalty to the product is weaker. This is because of the variety of prices and the number of websites offering alternative comparable products, increasing the competition, and raising the bargaining power of the consumer.

Research examining the disadvantages of purchasing online, found that the main disadvantage was the lack of interpersonal interaction. One of the solutions suggested was the use of avatars (virtual figures used as a company representative). It was found that an attractive avatar will have a stronger effect on customers with lower levels of involvement, while customers with higher levels 
won't be as influenced by the visual representation of the avatar (Holzwarth, Janiszewski, \& Neumann, 2006).

\section{The Influence of Social Networks: Word of Mouth} Communication 
"Abundant research demonstrates that word of mouth (WOM) is one of the most influential channels of communication in the marketplace. The reasons for WOM's power are evident: word of mouth is seen as more credible than marketer-initiated communications because it is perceived as having passed through the unbiased filter of 'people like me'" (Allsop, Bassett, \& Hoskins, 2007). Through research in the field of interpersonal communications, it was found that the transfer of information through word of mouth communication, effects positions and decisions of consumers, as well as the spread of ideas. There is a wide agreement that interaction between consumers may highly influence the consumer's perception of a brand. Human interactions fulfill a vital role in the dissemination of products of and services (Kumar et al., 2010). Beyond the purchase behavior, consumers are able to build up or destroy a company's reputation by either sharing positive or negative reviews or feedback. Through this social information transfer, there is influencing potential on both ends; both the sender and receiver's opinions can be swayed. According to Buttle (1998), positive word of mouth occurs when the product or service meets or exceeds the customer's expectations. Negative word of mouth spreads in the opposite scenario when expectations are not met. Credibility has a key role in word of mouth communication when referring to it as a tool of persuasion. It was found that credibility is a factor that significantly changes the opinions of those receiving information. In cases where the information was referred by a reliable source of information, it possesses a higher influence on the receiver, and in the same way, if an unreliable source shares information, this word of mouth transfer is far less trusted and effective (Cheung, Lee \& Rabjohn, 2008). Additionally, it was found that people perceive another consumer's recommendation as more reliable than the recommendation of an expert (O'Reilly \& Marx, 2011).

The online environment provides other areas of sharing consumer's opinions, preferences, and experience. It also provides opportunities for commercial companies to use this positive word of mouth phenomenon to their benefit (Kumar, et al., 2010). There are a number of unique characteristics in online word of mouth communication that has led to the sophistication, 
improvement, and effectiveness of this concept, compared to the classic word of mouth communication (Hoffman \& Novak, 1996). In the digital age, with the drop of faith in traditional advertisements, word of mouth communication became the most influential channel available (Lin, Lee, \& Horng, 2011). Verlegh and Moldovan (2008) argues that because of the decrease of consumer confidence in traditional advertisement, word of mouth communication marketing has become a main component utilized throughout strategic marketing, due to it's function as a powerful persuasion tool (Huang et al., 2011). Beyond and Lexis (2011) discovered that recommendations from friends and family act as the second most effective purchasing persuasion tool, after online research. Additionally they found that high sharers prove to be the most valuable to brands as they recommend products 3 times more frequently and thereby influence others' purchases. By identifying high sharers, their preferred channels, and the reasons why they share, marketers can then engage them with sharable content, which increases the dynamic of sharing. This acts as a positive amplifier leading into a helpful cycle of recommendation, loyalty and consumer purchases (Beyond \& Lexis, 2011).

One of the most central influences of social networks is the expansion of "the ripple effect" and broadening the impact of word of mouth communications. The ripple effect refers to the way of information transfer in word of mouth communications, which extends word of mouth information through a chain reaction that eventually spreads to the broader consumer population (Huang et al., 2011). Hartmann et al. (2008) describe another communication phenomenon known as "the spillover effect". This refers to the marketing effort in social networks that began with marketers targeting social influencers who shape opinions online. In this way, people can learn about a product without being directly exposed to the advertisement. According to Hartmann, the influencer who spreads the information has a significant role in the information transfer chain by being the unlikely link, connecting two sources. When someone is willing to share, the length of the chain of information grows and through this, the ripple effect comes into play. 
According to Huang et al., (2011), there are two parameters for enhancing the ripple effect. First, the consumer can share their experience with an unlimited number of people around them, acting as the width of the chain. Second, the possible encounters of connections that share the information, making the chain longer. (See Figure 11)

Huang et al., (2011) examined the factors that influence the decision making process, following a word of mouth effort. They found four factors that have significant influence on how information is received: quality, authenticity, interest, and authority. In order for the participants in the process of word of mouth communication to trust the information, the information needs to adhere to these criteria. Furthermore, when information is spread by word of mouth, even when the sender is no expert on what they are recommending, the people they tell will value their insights.

In classic word of mouth communication (face to face), the level of effectiveness depends on the way the sender conveys his message. Contrastingly, online, the origin of a message is not always so clear. In this case, there is no sender necessarily being evaluated, and instead, what the consumer is judging by, comes from whatever limited information is available (Huang et al., 2011).

\section{The Engagement Between Consumers and Brands in the Digital Age}

Brands wish to establish a deep and meaningful connection with those who consume their products, in order to engrain in them loyalty and a long lasting relationship. Muniz and O'Guinn (2001), define a brand community as "a specialized, non-geographically bound community, based on a structured set of social relations among admirers of a brand." This connection is part of a behavior that is fundamental within humans. It possesses a deeper meaning than the 
concept of deals and purchases, as an expression of the consumer's behavior towards the brand or company (Kumar et al., 2010). According to the classic approach, the consumer does not participate in the decisions and values of a commercial company. Instead, they are seen as passive in relation to the brand and their ability to influence the products of a commercial company, in a direct and immediate manner. In the past, there was almost no way to communicate directly with such companies and impact their decision making process. Looking at the three steps of a purchase, before, during, after, there was no link in communication (Bijmolt et al., 2010). Van Doorn et al. (2010) claims that the development of the Internet and social media brought a significant change in the reciprocal relationship between the consumer and the company. In the age of social networks, consumers can cooperate in the process of company innovation, through every aspect of product development. They now have a greater role than ever, with the new ability to influence the values and competitive strategies of a company. This leads to the possibility of an overall increase in involvement with the product and ultimately the brand.

According to Kumar et al., (2010), the measurement of the consumers value focused traditionally on attracting them, keeping them, and monetizing this connection through consumer purchases over time. This connection produced even more beneficial results through word of mouth communication, suggestions for improvement and new products, and more. Today more than ever, commercial companies identify this need for the company/consumer interpersonal relationship.

\subsection{The Consequences of Emotional Involvement in Commercial Companies}

Van Doorn et al., (2010) studied the consequences of consumer behavior when they establish an emotional relationship with commercial companies. Online involvement has financial consequences- many behaviors such as recommendation and participation in word of mouth communication, and creation and distribution of information, have an influence on the purchase behaviors of 
other consumers. As mentioned earlier, it is possible to quantify and measure the financial and intrinsic value of these behaviors. Another consequence is the influence on the company's reputation- consumers who are connected to the brand and emotionally invested in it, can contribute to the reputation and the overall brand image, by participating in brand communities and supporting events connected to the brand, such as charities and fundraisers. A third consequence of this link is that active and involved clients can spread information in a wide variety of activities such as idea proposal for design and development of products. Through consumer proposals, companies can reach higher levels of effectiveness and consumer satisfaction, improving the overall consumer wellbeing in regard to the service. Eventually this may reduce the amount of complaints and negative feelings and feedback, which leads to financial benefits, thanks to the reduction of costs in these areas.

\section{Discussion}

It is a rare phenomenon to exist in this generation of such exorbitant change. With the introduction of the Internet into our homes and integration of social network usage into every aspect of life, people are connecting in new ways that can improve and simplify many situations in their lives.

As a result of the Internet, the way consumers communicate changed dramatically. This revolutionized the way consumers exchange information about different products, as well as the way they consume them. From the vast papers and studies taken into account in this paper, it was noted that the process of consumer decision-making is dynamic, with the essential change arising with the stage of information search and availability online. It was found that the Internet 
has become more effective than ever, and today, through this platform, virtually any audience in the world can be reached and connected with endless information, while exerting minimal costs of time, money, and effort. Information was previously only made available through traditional means of communications and advertisements, but today can be accessed through more outlets than ever, including: retailers, sales, customer service representatives, face to face communication, Facebook page and other social networking sites, word of mouth communication, online word of mouth communication, family, friends, customers, or experts. The literature reviewed in this paper led to the conclusion that the attitudes of companies and brands are adapting to the times and the different new forms of communications. While in the past, companies and brands may have mastered traditional customer relations through one directional messages, without taking into account consumer reactions, comments, and feedback, today this has evolved into a much more complex yet effective, two way communication. Customers can now publicly reveal positive or negative feedback about these companies. While consumers used to hold a less powerful position in influencing purchase decisions, they have now been made very influential, through consumer discussions regarding products and raising awareness about their experiences. The use of the Internet and social networks holds benefits overall for consumers and businesses. The power of the consumer has grown and decision-making capabilities have improved through the effectiveness of this process and the decrease in purchase costs and risks. New channels of interactive and direct communication are now open to the business world, encouraging the formation of a deeper long-term relationship, while increasing customer satisfaction and enhancing loyalty. 


\section{References:}

Allsop, D.T., Bassett, B.R., Hoskins, J.A. (2007). Word-of-mouth research: principles and applications. Journal of Advertising Research, 398-411.

Amichai-Hamburger, Y., \& Hayat, T. (2017). Social Networking. The International Encyclopedia of Media Effects.

Bagozzi, R.P., \& Dholakia, U.M. (2002). Intentional social action in virtual communities. Journal of Interactive Marketing, 16(2), 2-21.

Beatty, S.E., \& Smith, S.M. (1987). External search effort: An investigation across several product categories. Journal of Consumer Research, 14, 8395.

Beyond \& Lexis. (2011). The Science of Sharing. bynd.com/wpcontent/uploads/2011/science-of-sharing-uk.pdf

Bijmolt, T.H., Leeflang, P.S., Block, F., Eisenbeiss, M., Hardie, B.G., Lemmens, A., \& Saffert, P. (2010). Analytics for customer engagement. Journal of Service Research, 13(3), 341-356.

Boyd, D.M., \& Ellison, N.B. (2007). Social network sites: Definition, history, and scholarship. Journal of Computer Mediated Communication, 13(1), 210230.

Buttle, F.A. (1998). Word of mouth: Understanding and managing referral marketing. Journal of Strategic Marketing, 6(3), 241-254. 
Chai, L.T., Ling, K.C., \& Piew, T.H. (2010). The effects of shopping orientations, online trust and prior online purchase experience toward customers' online purchase intention. International Business Research, 3(3), 63-76.

Cheung, C.M.K., Lee, M.K.O., \& Rabjohn, N. (2008). The impact of electronic word-of-mouth: The adoption of online opinions in online customer communities. Internet Research, 18(3), 229-247.

Chu, S.C., \& Sung, Y. (2015). Using a consumer socialization framework to understand electronic word-of-mouth (eWOM) group membership among brand followers on Twitter. Electronic Commerce Research and Applications, 14(4), 251-260.

ComScore. (2011). It's a Social World: Top 10 Need-to-Knows About Social Networking and Where It's Headed. www.comscore.com/it_is_a_social_world.

Constantinides, E. (2004). Influencing the online consumer's behavior: The web experience. Internet Research, 14(2), 111-126.

De Vries, L., Gensler, S., \& Leeflang, P. S. (2012). Popularity of brand posts on brand fan pages: an investigation of the effects of social media marketing. Journal of Interactive Marketing, 26(2), 83-91.

Digitas (2012). Social Commerce Study. www.pitchengine.com/digitas/digitasstudy-finds-security-is-key-to-social-commercegrowth-55-of-social-mediausers-not-comfortable-giving-credit

eMarketer (2013). On Facebook, Retailers Tackle how best to Drive Sales. www.emarketer.com/Article/On-Facebook-Retailers-Tackle-How-BestDrive-Sales/1009793\#2h74EMYxt0C4cRIK.99 
Fleishman-Hillard. (2012). Digital Influence Index: Understanding the Role of the Internet in the Lives of Consumers. push.fleishmanhillard.netdnacdn.com/dii/2012-DII-White-Paper.pdf

Hartmann, W.R., Manchanda, P., Nair, H., Bothner, M., Dodds, P., Godes, D., Hosanagar, K. and Tucker, C. (2008), Modeling social interactions: Identification, empirical methods and policy implications. Marketing Letters, 19(3-4), 287-304.

Haubl, G., \& Trifts, V. (2000). Consumer decision making in online shopping environments: The effects of interactive decision aids. Marketing Science, 19(1), 4-21.

Hayat, T. Z., Lesser, O., \& Samuel-Azran, T. (2017). Gendered discourse patterns on online social networks: A social network analysis perspective. Computers in Human Behavior, 77, 132-139.

Hayat, T., Samuel-Azran, T., \& Galily, Y. (2016). Al-Jazeera Sport's US Twitter followers: Sport-politics nexus?. Online Information Review, 40(6), 785797.

Hayat, T., \& Samuel-Azran, T. (2017). "You too, Second Screeners?" Second Screeners' Echo Chambers During the 2016 US Elections Primaries. Journal of Broadcasting \& Electronic Media, 61(2), 291-308.

Hennig-Thurau, T., Malthouse, E.C., Friege, C., Gensler, S., Lobschat, L., Rangaswamy, \& Skizra, B. (2010). The impact of new media on customer relationships: From bowling to pinball. Journal of Service Research, 13(3), 311-330. 
Hoffman, D.L. \& Novak, T.P. (1996). Marketing in hypermedia computermediated environments: Conceptual foundations. Journal of Marketing, 60(3), 50-68.

Holzwarth, M., Janiszewski, C., \& Neumann, M.M. (2006). The influence of avatars on online consumer shopping behavior. Journal of Marketing, 70(4), 19-36

Hoyer, W.D., Rajesh, C., Matilda, D., Manfred, K., \& Siddarth, S.S. (2010). Consumer co-creation in new product development. Journal of Service Research, 13(3), 283-296.

Huang, M., Cai, F. Tsang, A.S.L., \& Zhou, N. (2011). Making your online voice loud: The critical role of WOM information. European Journal of Marketing, 45(7), 1277-1297.

Jusoh, Z. M., \& Ling, G.H. (2012). Factors influencing consumers' attitude towards e-commerce purchases through online shopping. International Journal of Humanities and Social Science, 2(4).

Kaplan, A.M., \& Haenlein, M. (2010). "Users of the world, unite! The challenges and opportunities of social media". Business Horizon, 53(1), 59-68.

Koufaris, M. (2002). Applying the technology acceptance model and flow theory to online consumer behavior. Information Systems Research, 13(2), 205223.

Kumar, V., Aksoy, L., Donkers, B., Venkatesan, R., Wiesel T., \& Tillmanns S. (2010). Undervalued or overvalued customers: Capturing total customer engagement value. Journal of Service Research, 13(3), 297-310. 
Lakshmi, P. V., (2011). Purchasing involvement: a potential mediator of buyer behavior. Petroleum-Gas University of Ploiesti Bulletin, 63(2), 23-37.

Latta, M.M., \& Thompson, C.M. (2011). How YouTube has provided new ways to consume, create, and share music. International Journal of Education \& the Arts. 12 (6).

Lempert, P. (2006). Caught in the Web. Progressive Grocer, 85, 12-18.

Letierce, J., Passant, A., Breslin, J., \& Decker, S. (2010). Understanding how Twitter is used to spread scientific messages. Paper presented at the Web Science Conference. Raleigh, NC, USA.

Li, C. \& Bernoff, J. (2008). Groundswell: Winning in a World Transformed by Social Technologies. Boston: Harvard Business Press.

Lin, C. L., Lee, S. H., \& Horng, D. J. (2011). The effects of online reviews on purchasing intention: The moderating role of need for cognition. Social Behavior and Personality, 39(1), 71-81.

Liu, Y. \& Shrum, L.J. (2002). What is interactivity and is it always such a good thing? Implications of definition, person, and situation for the influence of interactivity on advertising effectiveness. Journal of Advertising, 31, 4, 5364.

Mangold, W.G., \& Faulds, D.J. (2009). Social media: The new hybrid element of the promotionmix. Business Horizons, 52(4), 357-365.

McClard, A., \& Anderson, K. (2008). Focus on Facebook: Who are we anyway? Anthropology News, 49(3), 10-12. 
Muniz, A.M., \& O'Guinn, T.C. (2001). Brand community. Journal of Consumer Research, 27(4), 412-432.

Nanji, A. (2013). How Facebook, Twitter, and Pinterest sharing affects sales. Marketing Profs. www.marketingprofs.com/charts/2013/11154/how-facebook-twitter-andpinterest-sharingaffects-sales\#ixzz2aNDjsvIM

Nielsen. (2011). The Social Media Report: State of the Media, q3 2011. blog.nielsen.com/nielsenwire/social/

Nielsen. (2012). Global Survey of Online Shopping. es.nielsen.com/site/documents/NielsenGlobalDigitalShoppingReportAugu s $\quad$ t2012.pdf

O'Reilly, K., \& Marx, S. (2011). How young, technical consumers assess online WOM credibility. Qualitative Market Research, 14(4), 350-359.

Peterson, R.A., \& Merino, M.C. (2003). Consumer information search behavior and the Internet. Psychology and Marketing, 20(2), 99-121.

Pew Internet \& American Life Project. (2011). 65\% of Online Adults Use Social Networking Sites. pewlnternet.org/Reports/2011/Social-NetworkingSites.aspx

Pew Internet \& American Life Project. (2013). The Demographics of Social Media Users - 2012. pewlnternet.org/Reports/2013/Social-media-users.aspx 
Pew Internet \& American Life Project. (2015A). Numbers, Facts, and Trends Shaping the World. pewlnternet.org/files/2015/01/PI_SocialMediaUpdate20144.pdf

Pew Internet \& American Life Project. (2015B). Americans' Internet Access: 2000-2015. pewInternet.org/2015/06/26/americans-Internet-access-20002015/

Reichheld, F.F., Markey, R.G. Jr. \& Hopton, C. (2000). The loyalty effect: The relationship between loyalty and profits. European Business Journal, 12 (3), 134-139.

Riegner, C. (2007). Word of mouth on the Web: The impact of Web 2.0 on consumer purchase decisions. Journal of Advertising Research, 47(4), 436-447.

Shankar, V., Smith, A.K., \& Rangaswamy, A. (2003). Customer satisfaction and loyalty in online and offline environments. International Journal of Research in Marketing, 20(2), 153-175.

Steuer, J. (1992). Defining virtual reality: dimensions determining telepresence. Journal of Communication, 42 (4), 73-93.

Van Doorn, J., Lemon, K.N., Mittal, V., Nass, S., Pick, D., Pirner, P., \& Verhoef, P.C. (2010). Customer engagement behavior: Theoretical foundations and research directions. Journal of Service Research, 13(3), 253-266.

YouTube (2015). YouTube Statistics (Date file). Retrieved from youtube.com/yt/press/statistics.html 
Zhang, C.B., \& Lin, Y.H. (2015). Exploring interactive communication using social media. The Service Industries Journal, 35(11-12), 670-693.

\section{Appendices}

Figure 1: American Adult Internet Usage Growth

\section{4\% of American Adults Use the Internet}

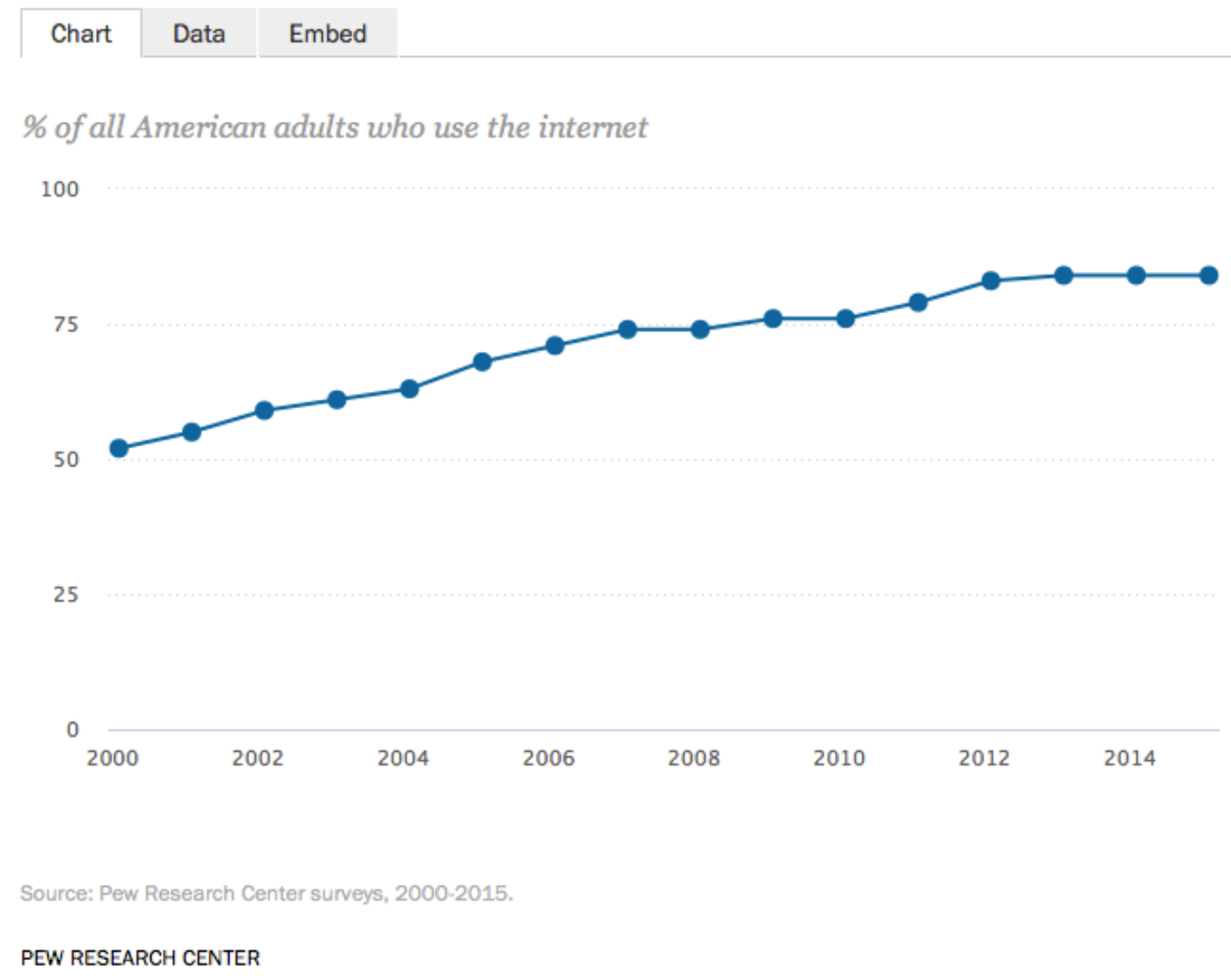

Figure 2: Classification of Social Media by social presence/media richness and self-presentation/self-disclosure. 


\begin{tabular}{|c|c|c|c|}
\cline { 2 - 4 } \multicolumn{1}{c|}{} & Low & \multicolumn{2}{c|}{ Social presence/ Media richness } \\
\multicolumn{1}{c|}{ High } & Blogs & $\begin{array}{c}\text { Social networking sites } \\
\text { (e.g., Facebook) }\end{array}$ & $\begin{array}{c}\text { Virtual social worlds } \\
\text { (e.g., Second Life) }\end{array}$ \\
$\begin{array}{c}\text { Self- } \\
\text { presentation/ } \\
\begin{array}{c}\text { Self- } \\
\text { disclosure }\end{array}\end{array}$ & $\begin{array}{c}\text { Collaborative } \\
\text { projects } \\
\text { (e.g., Wikipedia) }\end{array}$ & $\begin{array}{c}\text { Content communities } \\
\text { (e.g., YouTube) }\end{array}$ & $\begin{array}{c}\text { Virtual game worlds } \\
\text { (e.g., World of Warcraft) }\end{array}$ \\
\hline
\end{tabular}

Figure 3: Social networking site use by age group, 2005-2011. The percentage of adult Internet users in each age group who use social networking sites.

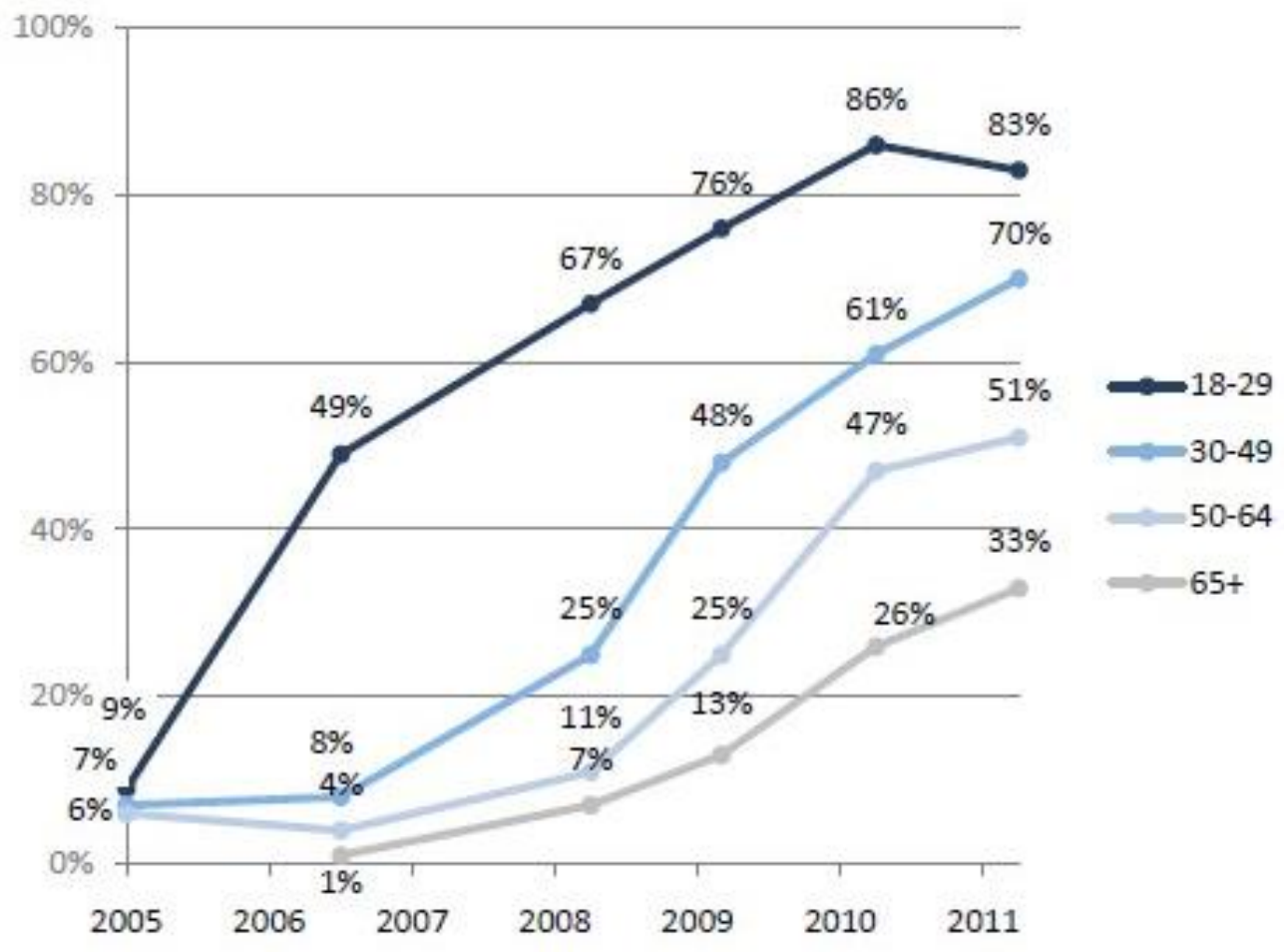

Note: Total $\mathrm{n}$ for internet users age $65+$ in 2005 was $<100$, and so results for that group are not included.

Source: Pew Research Center's Internet \& American Life Project surveys: February 2005, August 2006, May 2008, April 2009, May 2010, and May 2011. 
Figure 4: Social media sites, 2012-2014. \% of online adults who use the following social media websites, by year.
$=2012$
$\approx 2013$
- 2014

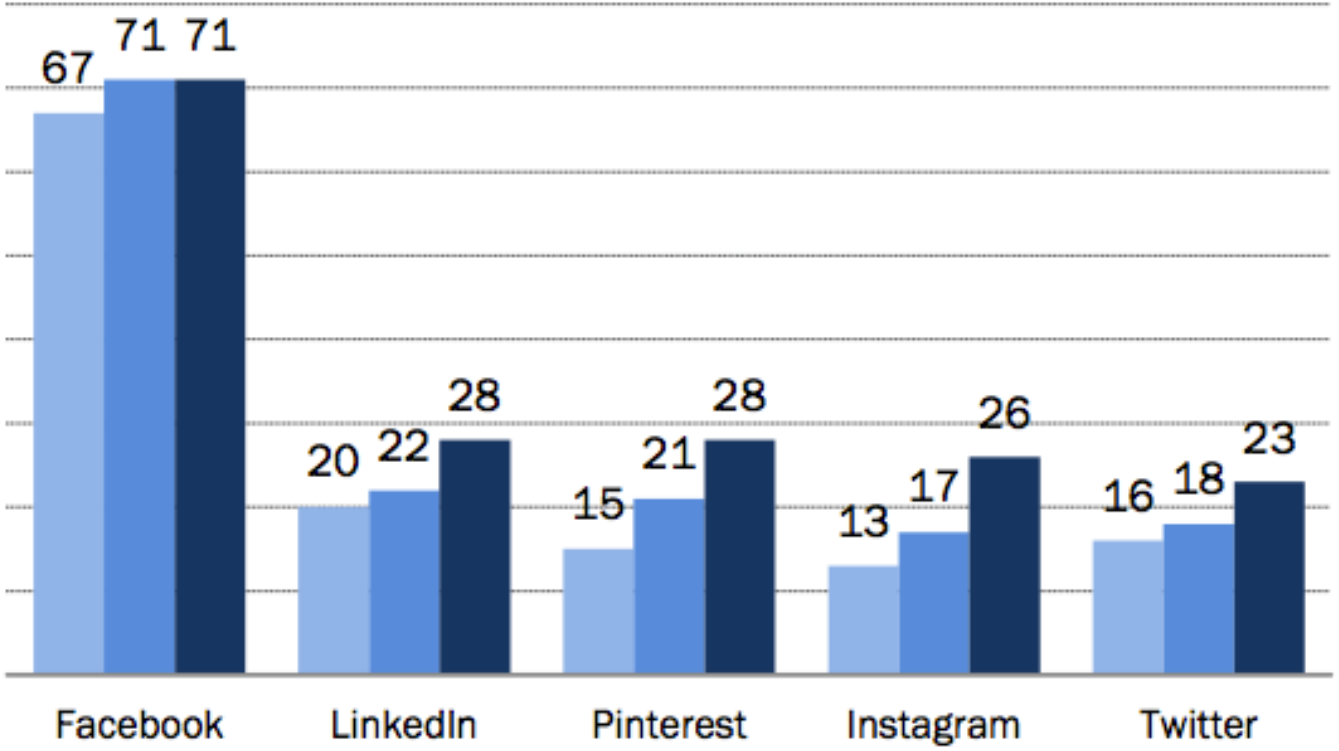

Pew Research Center's Internet Project Surveys, 2012-2014. 2014 data collected September 11-14 \& September 18-21, 2014. N=1,597 internet users ages 18+. PEW RESEARCH CENTER

Figure 5: Involvement Chart 


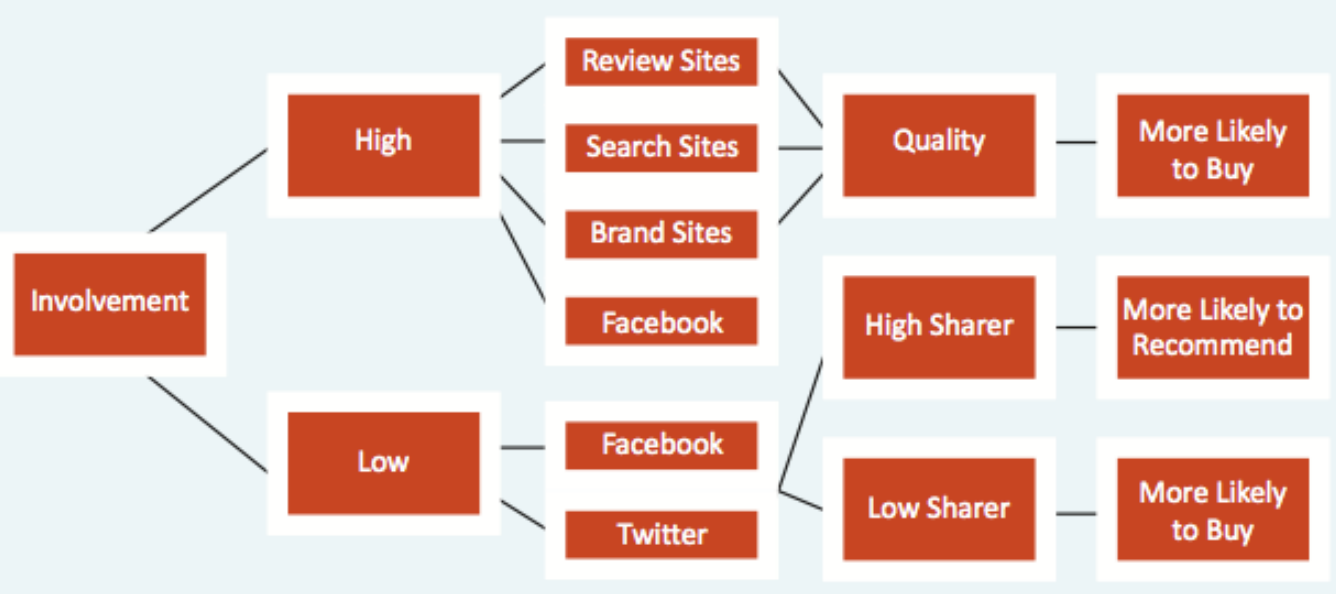

Figure 6: How the Internet Helps Consumers Make Decisions

\begin{tabular}{|c|c|c|c|c|c|c|c|}
\hline & \multirow[b]{2}{*}{$\begin{array}{l}\text { (All numbers } \\
\text { are percents) }\end{array}$} & \multicolumn{6}{|c|}{ The Internet helped you..... } \\
\hline & & $\begin{array}{l}\text { Find advice or } \\
\text { support from } \\
\text { other people } \\
\text { about: }\end{array}$ & $\begin{array}{l}\text { Compare } \\
\text { options }\end{array}$ & $\begin{array}{l}\text { Find } \\
\text { professional } \\
\text { or expert } \\
\text { services }\end{array}$ & $\begin{array}{l}\text { Act } \\
\text { faster }\end{array}$ & $\begin{array}{l}\text { Act with } \\
\text { more } \\
\text { confidence: }\end{array}$ & $\begin{array}{l}\text { Save } \\
\text { money }\end{array}$ \\
\hline \multirow{9}{*}{ 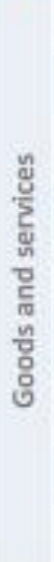 } & Packaged goods & 40 & 57 & 34 & 37 & 45 & 43 \\
\hline & Education & 67 & 77 & 53 & 74 & 64 & 87 \\
\hline & Healthcare & 75 & 80 & 72 & 72 & 74 & 69 \\
\hline & Public affairs & 67 & 64 & 38 & 62 & 70 & 35 \\
\hline & Personal finances & 40 & 87 & 47 & 71 & 71 & 70 \\
\hline & Travel and leasure & 44 & 89 & 46 & 78 & 66 & B8 \\
\hline & $\begin{array}{l}\text { Consumer } \\
\text { electronics }\end{array}$ & 48 & 93 & 24 & 51 & 73 & 68 \\
\hline & Utilities & 56 & 84 & 54 & 69 & 65 & 80 \\
\hline & Children & 85 & 88 & 81 & 75 & 81 & 76 \\
\hline
\end{tabular}

Figures reflect the average percentage of consumers who indicated the internet helped them do one of the following (colums) when making a decision reganding the goods and/or services (row), figures are the anerage for the consumers in all eight cauntries. 
Figure 7: Information Search about Brands Online: Comparing between Countries

\begin{tabular}{|c|c|c|c|c|c|c|c|c|c|}
\hline $\begin{array}{l}\text { (All numbers } \\
\text { are percents) }\end{array}$ & & & $\star ?$ & & & (.) & & ॠथ & 㝘 \\
\hline Use a search engine & 89 & 93 & 90 & 96 & 91 & 88 & 78 & 90 & 90 \\
\hline $\begin{array}{l}\text { Go to the brand or } \\
\text { product website }\end{array}$ & 60 & 63 & 63 & 65 & 54 & 55 & 41 & 62 & 67 \\
\hline $\begin{array}{l}\text { Go to a product } \\
\text { review site }\end{array}$ & 50 & 47 & 53 & 47 & 50 & 55 & 49 & 55 & 43 \\
\hline Search a news site & 24 & 15 & 38 & 8 & 10 & 28 & 16 & 20 & 10 \\
\hline $\begin{array}{l}\text { Ask or post a question } \\
\text { on a forum }\end{array}$ & 24 & 12 & 42 & 9 & 11 & 33 & 6 & 12 & 8 \\
\hline $\begin{array}{l}\text { Go to the brand } \\
\text { or product's } \\
\text { Facebook page }\end{array}$ & 18 & 14 & 28 & 8 & 5 & 35 & 7 & 9 & 8 \\
\hline $\begin{array}{l}\text { Go to the brand or } \\
\text { product's Twitter feed }\end{array}$ & 14 & 3 & 28 & 0 & 1 & 21 & 7 & 5 & 1 \\
\hline $\begin{array}{l}\text { Search Twitter for } \\
\text { user comments }\end{array}$ & 12 & 2 & 22 & 1 & 1 & 20 & 7 & 6 & 1 \\
\hline Something else & 5 & 7 & 5 & 4 & 11 & 11 & 4 & 4 & 4 \\
\hline $\begin{array}{l}\text { Not applicable- } \\
\text { I do not search for } \\
\text { information about } \\
\text { brands or products on } \\
\text { the Internet }\end{array}$ & 4 & 5 & 0 & 2 & 6 & 4 & 11 & 5 & 6 \\
\hline
\end{tabular}

Figure 8: Reasons Why Consumers Follow Brands on Social Networks 


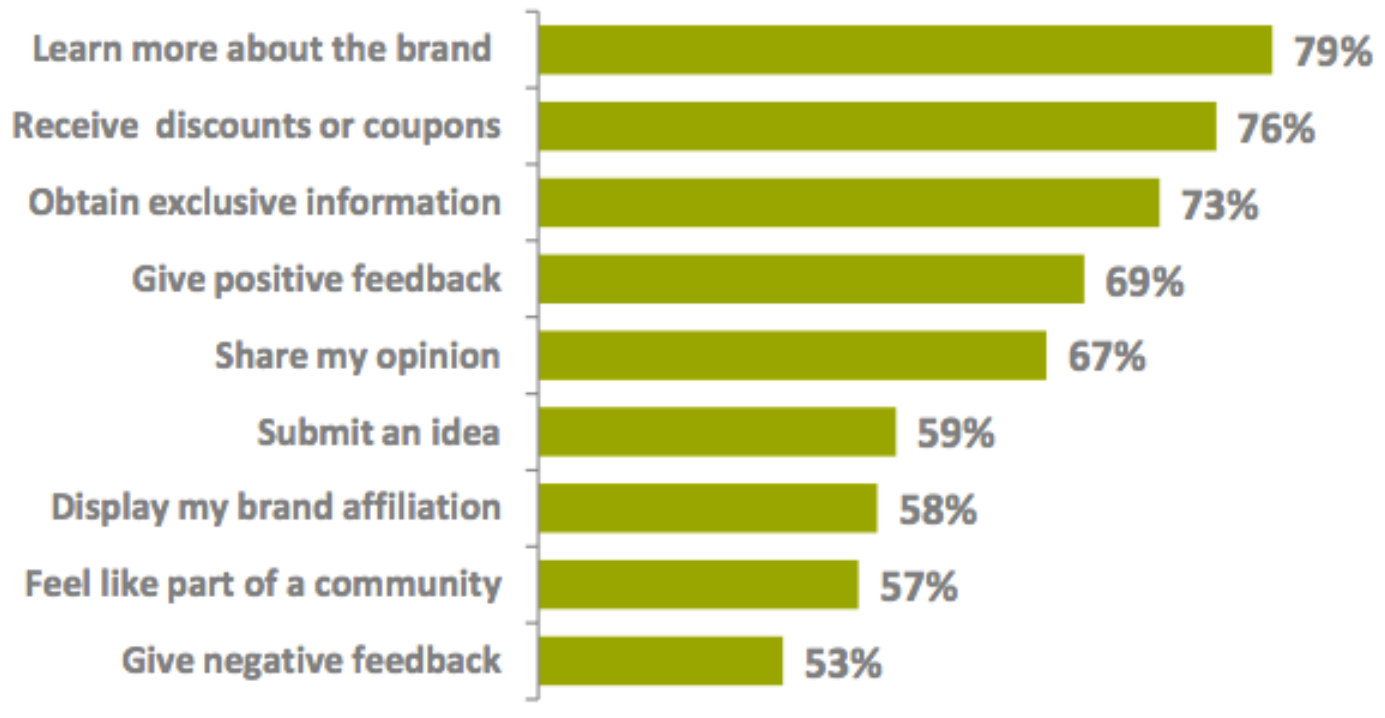

Figure 9: Factors affecting the online consumer's behavior

Forces influencing the online consumer's behavior

\section{Other stimuli: Personal and \\ Environmental Uncontrollable Factors}

Demographic, personal, cultural,

sociological, economic, legal, environmental etc.

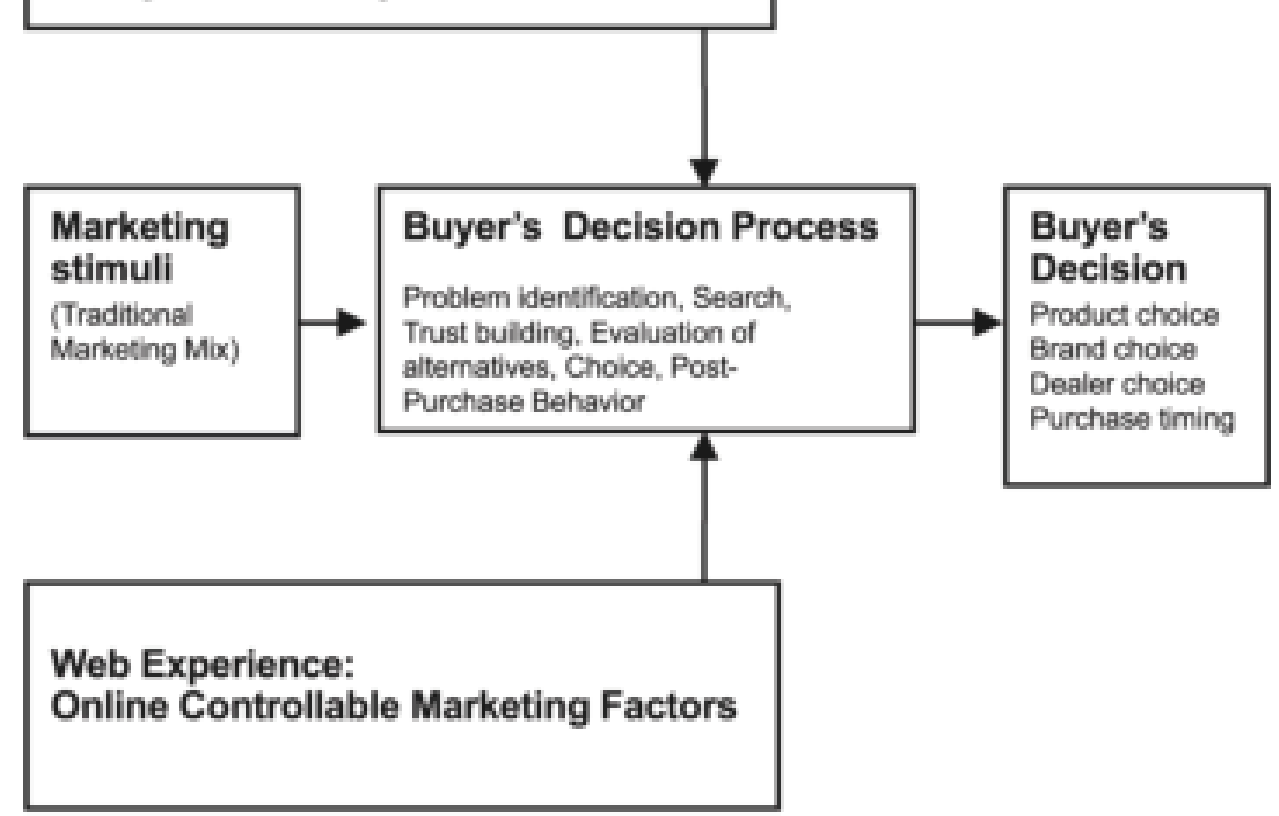

Source: Based on the P. Kotler's framework (2003) 
Figure 10: Mobile In-Store Research: how in-store shoppers are using mobile devices

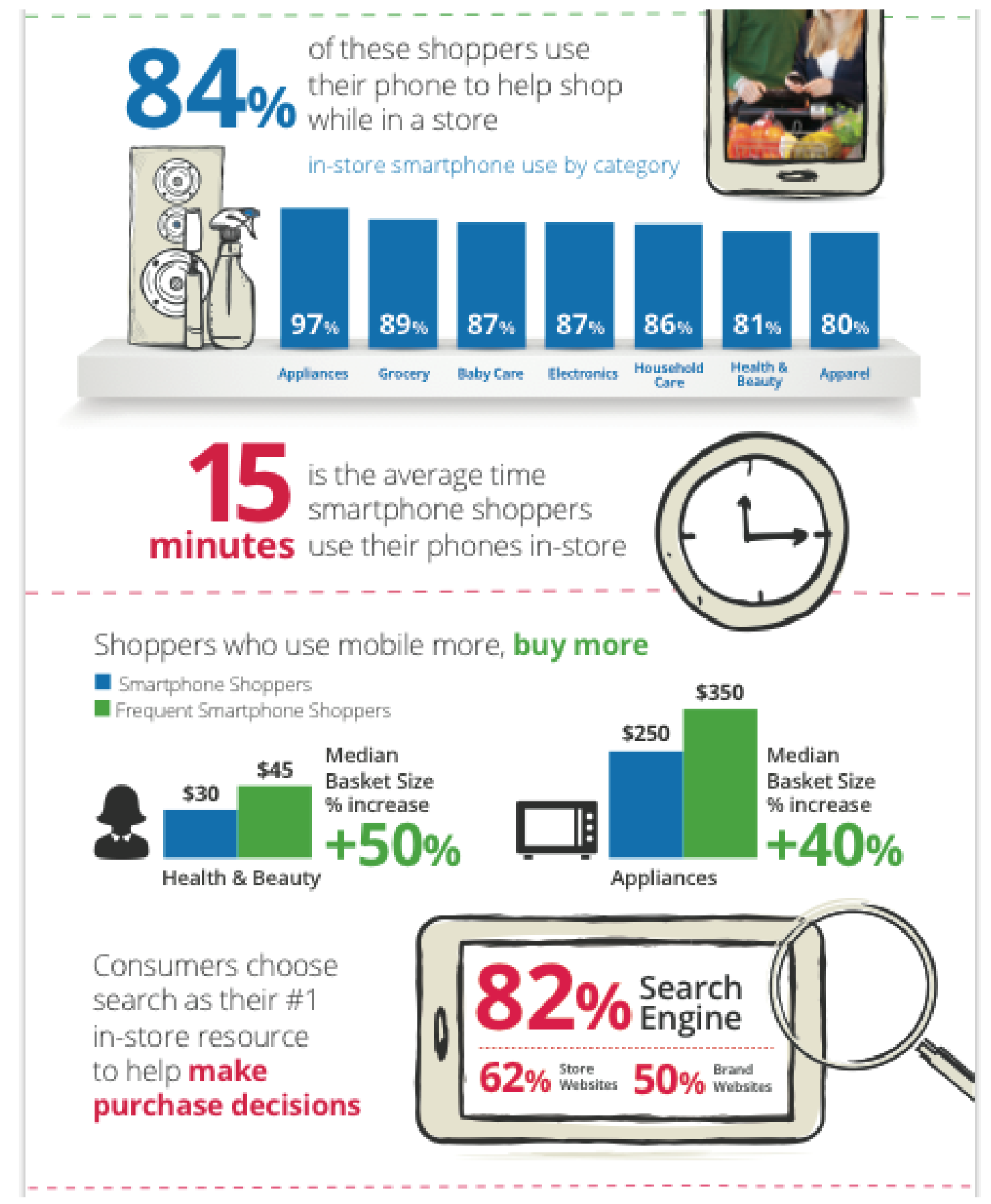


Figure 11: Ripple effect of word of mouth activities.

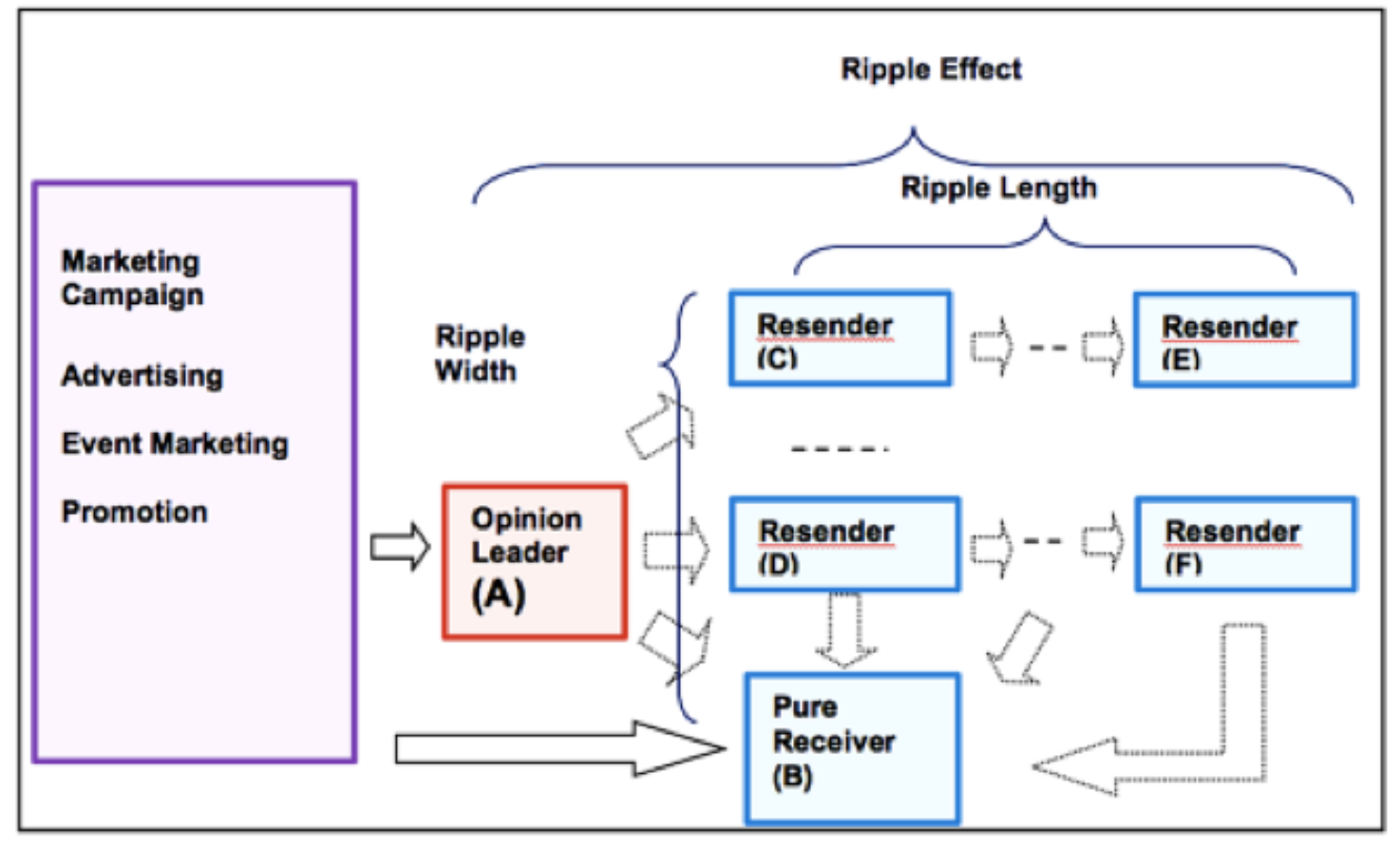

